large portion of the British Islands lying between lat. $52^{\circ}$ and $58^{\circ}$, the mean temperature of the five days was at least $6^{\circ} .0$ under the average of the season, and in the central portion of this district, as at York and Barrow-inFurness, it was $8^{\circ} \cdot 3$ under the average. On the other hand, in Jersey the defect from the mean was only ${ }^{\circ} .5$, and in Shetland $2^{\circ} \cdot 5$. At Barrow-in-Furness, on the 12 th, the maximum temperature was only $39^{\circ} \mathrm{O}$. Un this day snow fell over the higher districts of central and southern Scotland, in many places to the depth of several inches, and the cold was so intense that swallows and some other birds perished in thousands.

Meanwhile torrents of rain were being poured down continuously over wide districts of northern and central England. These rains were heaviest and most widespread on the IIth, I th, and I 3 th, on each of these days upwards of an inch being recorded in many places. Mr. Scott states in the Weekly Weather Report that during these three days falls of 4.83 inches occurred at Churchstoke, Montgomeryshire; 436 inches at Hereford; 4.15 inches at Pershore, Worcestershire ; 3.38 inches at Ross, Herefordshire; and 3.44 inches at Fassaroe, county Wicklow. Extensive and disastrous floods were the consequence. The railway traffic between Worcester, Hereford, and Malvern was suspended, and the whole of the united valley of the Severn and Teme, in the neighbourhood of Worcester, was laid under water. At Gloucester large numbers of the inhabitants were driven from their homes. The valley of the Trent presented the appearance of a vast lake, and the Midland Railway between Nottingham and Derby was submerged. Immense damage was done about Chester and along the estuary of the Dee, over the low grounds bordering the Humber, and over extensive tracts of Yorkshire.

A noteworthy feature of the storm is shown in the weather maps for the morning of the 13 th, when the area of low pressure extending from west to east over the south of England was broken up, and showed three satellite cyclones with still lower pressures, having their centres the first to the west of Brest, the second over Somersetshire, and the third over Kent,--these all evidencing great, well-marked, and sharp local differences in the distribution of temperature and vapour. Further, a most remarkable satellite cyclone was seen near Perpignan, in the south of France, which in all probability represented the small cyclone or tornado that about seven o'clock of the previous evening wrought such dreadful havoc in Madrid, causing 32 deaths, seriously wounding large numbers, variously estimated from 320 to 520 persons, and wrecking hundreds of houses. The area swept over by the tornado was comparatively limited, but within that area, as in the lower Carabanchel, not a house was left undamaged and many were wholly blown down, and hardly any of the inhabitants escaped uninjured. The storm was preceded by a sultry atmosphere, a heavy bank of black clouds in the north, and torrents of rain, and as so frequently occurs with the tornadoes of America, many buildings would appear to have fallen to pieces from an explosive force from within as the tornado passed overhead.

On the I4th violent cyclones or tornadoes occurred at Krossen, near Frankfort on the Oder, at Linz on the Danube, and at Lonato, $\mathrm{n} \subseteq$ ar Brescia, wrecking houses, and causing great destruction in other ways; and storms of less, but yet of considerable severity are reported from other parts of the Continent. It is to be hoped that some meteorologist of mark will undertake the discussion of these remarkable storms, so as to lead, if possible, to some knowledge of the peculiar meteorological conditions of Europe out of which they originated. In this discussion no little help will be given by the high-level observatories now established at so many points over Europe.

In the United States on May I I a tornado passed over Kansas City, Missouri, destroyed the court-house and other buildings, and partly demolished the bridge over the Missouri River, and thence pursued an easterly course to Pennsylvania, killing in its course about 90 persons, and injuring 300 . On the night of the $\mathbf{s}$ th terrible destruction was done by tornadoes in Ohio, Indiana, and Illinois. From 4 to 5 inches of rain fell within three hours, fully twenty miles of the Little Miami Railway were washed away, and at Xenia, where the waterspout was most destructive, 36 persons were drowned, 80 injured, and more than IOo houses destroyed. On the I 4th another series of tornadoes carried destruction through Ohio and Indiana; and on the 15 th a tornado, which appears to have formed on Lake Erie, penetrated 100 miles into Ohio. Its path was about 500 yards wide, and it levelled everything with the ground; killed $4 \mathrm{I}$ persons, and injured several hundreds. These, with other tornadoes of less severity occurring in Kansas and elsewhere, are stated to be the most severe and destructive storm; or tornadoes hitherto experienced in the United States, and the losses are estimated at about $5,000,000$ dollars.

The detailed reports of these remarkable storms will no doubt be prepared and circulated with the fulness and satisfactoriness which characterise the work and publications of the United States Signal Office; and, considering the striking simultaneousness of occurrence of these American and European storms from May II to I5, Gen. Hazen would, if the Reports were acco npanied and illustrated by international weather maps of the northern hemisphere from May 7 to 16 , lay meteorologists under a deep obligation.

\section{CRETACEOUS METAMORPHIC ROCKS}

$\mathrm{I}^{\mathrm{T}}$ is now a good many years since Prof. J. D. Whitney announced the existence of Cretaceous sediments in California which had undergone metamorphism into various crystalline rocks. The attention of geologists is once more directed to that region by the recent work of the Geological Survey of the United States. Mr. George F. Becker, whose admirable monograph on the great Comstock Lode has reflected such lustre on that Survey, has more recently been intrusted with the investigation of the quicksilver deposits of California. This research when completed will form the subject of another monograph in the same great series of publications. But in the meanwhile some results of such startling importance in metamorphism have been obtained that Mr. Becker has published in the American Fournal of Science a brief preliminary outline of them. It appears that the inquiry into the nature and origin of the rocks in question has been carried on partly by examination of their structure and relations in the field, partly by chemical analysis and partly by the study of microscopic sections. In short, all the appliances of modern geology have been enlisted in the investigation.

The area embraced by the rocks which are stated to have undergone metamorphism is estimated at 3000 square miles. The rocks are determined by fossils to be approximately of Neocomian age. They consist chiefly of sandstone and arkose lying upon and probably for the most part derived from granite. Their quartz-grains are cemented in great measure with carbonate of lime, and there are likewise clastic fragments of orthoclase, plagioclase, biotite, hornblende, and other minerals of the granite. From ordinary unaltered fossiliferous sandstones gradations are traceable into varieties wherein a process of recrystallisation has been set up, but has ceased before the fragmental character has been wholly effaced. In this process one of the first stages is often the resolution of the clastic grains into crystalline aggregates from which new minerals are built up. Thus the quartz-grains have had their surfaces so altered that an envelope of 
twinned felspar microliths has formed round them. These bodies lie approximately normal to the surface of the residual kernel, which they actually penetrate like pins set in a cushion. Zoisite also, which is present in nearly all the altered sandstones, as a product of metamorphism, sometimes pierces the quartz from outside. Augite and hornblende have likewise been developed, not infrequently as microliths, which, though grouped together in one common crystallographic outline, are not united.

Further stages of change are described as occurring in certain rocks where the fragmental character, though to the unaided eye still traceable, is found to have been replaced by an entirely crystalline structure, giving rise to rocks which must be classed with the diabases. These masses sometimes have their pyroxene in the form of diallage, and are destitute of olivine, but usually contain much zoisite and frequently also hornblende. Diorites of similar origin occur, sometimes with a predominance of hornblende as in true amphibolites.

The shales are silicified and intersected by innumerable quartz-veins, in which, or projecting from their walls, are frequently abundant zoisite crystals. Yet the metamorphism has not destroyed the microscopic fossils contained in the strata. But the most remarkable example of metamorphism cited by Mr. Becker is the conversion of these same felspathic sandstones into serpentine-an alteration referred to in Prof. Whitney's description of this region. He asserts that field observation conclusively proves the great mass of the serpentine, estimated altogether at more than 1000 square miles, to have been made out of the sandstones, either immediately or through an intermediate granular rock. Sections are seen where sandstone shades off into serpentine, and areas of highly-inclined sandstones pass along the strike into the same rock. In this conversion, the change begins along the cracks, working toward the centres of the included fragments, and producing a structure like that seen in decomposing olivine. The felspar fragments are corroded externally, their cracks being irregularly widened and filled with serpentine which sometimes projects as teeth into the clear felspathic mass. Even the quartzgrains have not been able to resist the alteration, but may be seen with their outer parts replaced by serpentine, which likewise penetrates their interior in long slender green needles. Apatite has also been replaced by serpentine, and the same transformation may be surmised in the case of mica and garnet. Mr. Becker states that chemical analyses and microscopic tests demonstrated that the serpentine diffused through the sandstones and forming the massive exposures is all the same mineral. He will no doubt in due time produce the detailed evidence on which his statements are founded. In the meantime he will of course be prepared for much scepticism and even for angry denial of his results. The careful elucidation of the problem he has attacked cannot but be of enormous service in throwing light upon the vexed question of metamorphism. He claims that the rocks which he has been investigating furnish a colossal example of regional metamorphism of which all the successive stages can be studied. Many thousands of square miles of rock have been subjected to such intense lateral compression that they have been utterly shattered, the average size of the unbroken lumps not being greater than that of an egg. In rocks thus crushed warm interstitial water would have potent chemical reactions. Warm basic solutions are believed to have first been produced, and to have converted the sandstones and some of the shales into holocrystalline compounds containing augite and hornblende. Serpentisation is supposed to have followed at a lower temperature, while silicification came last, as the solutions finally became acid. Geologists will await with impatience the appearance of the monograph in which these conclusions are maintained.

\section{THE COMPOSITION OF THE EDIBLE BIRD'S- NEST (COLLOCALIA NIDIFICA)}

$\mathrm{THE}$ nature of the material which forms the edible bird's-nest has been the subject of some controversy. In 1817 Sir Everard Horne (Phil. Trans., 1817, p. 337) suggested that it is the product of the activity of certain glandular structures which he figures in his paper, and which he associates with the gastric glands. In the "Origin of Species" (6th ed., p. 228) Darwin indorses the view of its being entirely a secretion by the bird, speaking of it as "inspissated saliva," and showing how the amount of saliva devoted to nest construction differs with different species. He mentions in particular a North American species which he says "makes its nest (as I have seen) of sticks agglutinated with saliva and even with flakes of this substance." Writing at about the same time, Bernstein (Fournal für Ornithologie, I859, p. III) connects the nature of the material with certain developments of the bird's salivary glands, which he says are noticeable during the nest-building season.

On the other hand, it has been maintained by many observers that the nest of this species of swift is con-

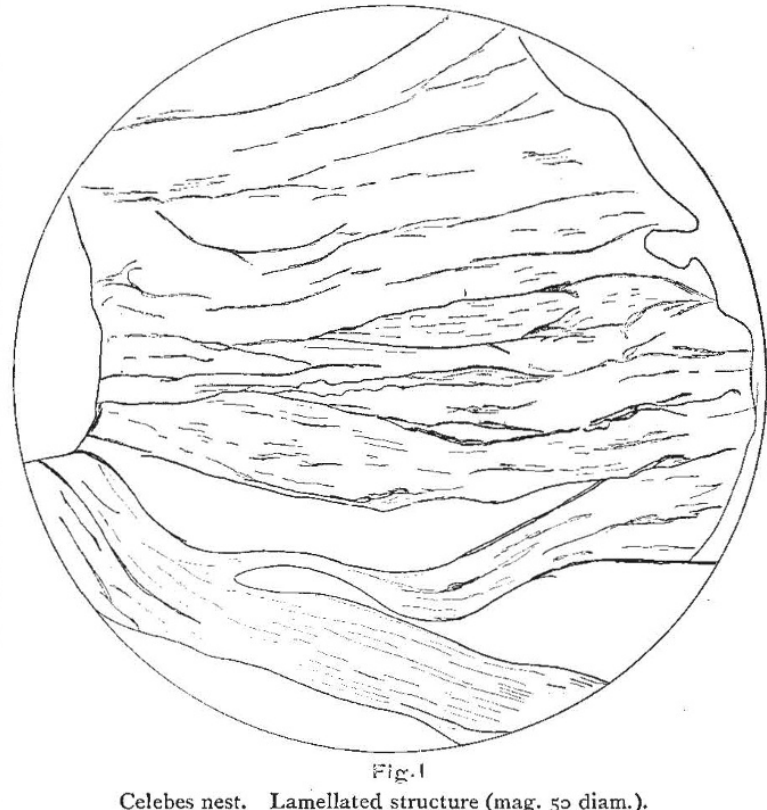

structed similarly to the North American species referred to by Darwin, the chief difference being that instead of sticks the bird uses certain algæ which are found in considerable masses on the walls of the caves which they frequent in the breeding season. Other algæ also have been suggested as those used.

It has further been supposed that the algæ are partially digested before being utilised, and that after regurgitation the material so acted on is worked up into the form of the nest.

A suggestion was made by Mr. E. L. Layard, H.M. Consul in New Caledonia, in a letter to NATURE, September 17,1884 (p. 82), which seemed to reconcile the conflicting theories. He says that the first quality of nest which is produced early in the breeding season consists entirely of animal secretion, but that later on, if the first nests are destroyed, the birds cannot replace them by this secretion alone, and so use extraneous substances to help in the construction. The second and inferior qualities of nest are so formed differently from the first.

In a paper published in the Fournal of Physiology (vol. vi. p. 40), I have given the results obtained from an 